\title{
KINEROS2 application for land use/cover change impact analysis at the Hulu Langat Basin, Malaysia
}

\author{
Hadi Memarian', Siva K. Balasundram², Jamal B. Talib' ${ }^{1}$, Christopher Teh Boon Sung ${ }^{1}$, Alias Mohd Sood ${ }^{3}$ \& \\ Karim C. Abbaspour ${ }^{4}$
}

${ }^{1}$ Department of Land Management, Faculty of Agriculture, Universiti Putra Malaysia (UPM), Serdang, Selangor, Malaysia, ${ }^{2}$ Department of Agriculture Technology, Faculty of Agriculture, Universiti Putra Malaysia (UPM), Serdang, Selangor, Malaysia, ${ }^{3}$ Department of Forest Production, Faculty of Forestry, Universiti Putra Malaysia (UPM), Serdang, Selangor, Malaysia and ${ }^{4}$ Eawag, Swiss Federal Institute of Aquatic Science and Technology, Duebendorf, Switzerland

\section{Keywords}

impact analysis; KINEROS2; LUCC; runoff; sediment.

\section{Correspondence}

S. Balasundram, Agriculture Technology, Faculty of Agriculture, Universiti Putra Malaysia, Agrobio Complex, Serdang, Selangor, 43400, Malaysia. Email: siva@putra.upm.edu.my; skbal71@gmail.com

doi:10.1111/wej.12002

\begin{abstract}
The impacts of land use/cover changes (LUCC) on a developed basin in Malaysia were evaluated. Three storm events in different intensities and durations were required for KINEROS2 (K2) calibration and LUCC impact analysis. K2 validation was performed using three other rainfall events. Calibration results showed excellent and very good fittings for runoff and sediment simulations based on the aggregated measure. Validation results demonstrated that the K2 is reliable for runoff modelling, while K2 application for sediment simulation was only valid for the period 1984-1997. LUCC impacts analysis revealed that direct runoff and sediment discharge increased with the progress of urban development and unmanaged agricultural activities. These observations were supported by the NDVI, landscape and hydrological trend analyses.
\end{abstract}

\section{Introduction}

Land use changes in river basins result in flooding events that increase sediment load, which is a global concern (GarciaRuiz et al. 2008; Zhang et al. 2008, 2010). Changes in land cover result in some proportional alterations in the basin condition and hydrological response. This is becoming one of the main land management issues (Hernandez et al. 2000).

Many studies about the impacts of human activities and climate change on the hydrological processes of rivers have been conducted (Nearing et al. 2005; He et al. 2008; Ghaffari et al. 2009; Li et al. 2009; Ouyang et al. 2010a). In recent years, application of process models has become an indispensable tool for understanding natural processes occurring at the catchment scale (Sorooshian \& Gupta 1995). A geographic information system (GIS)-based spatial modelling has become a very important tool in runoff and soil erosion studies and consequently in the development of appropriate soil and water conservation strategies, especially at the catchment scale. For instance, Miller et al. (2007) integrated landscape assessment and hydrological modelling for land cover change analysis. In their work, a landscape assessment tool using a GIS was developed to automate the parameterisation of the Soil and Water Assessment Tool (SWAT) and
KINEmatic Runoff and EROSion (KINEROS) hydrologic models. Runoff and sediment yield were simulated using these models. Results demonstrated the power of integrating remote sensing and distributed hydrological models through the GIS for assessing the basin condition and related impacts of the land cover transitions on the hydrological response. In another work performed by Hernandez et al. (2000), runoff response to the land cover and rainfall spatial variations in semi-arid catchments was modelled by the KINEROS2 (K2) and SWAT. Simulation results indicated that both models were able to characterise runoff response of the basin due to changes of the land cover. Ziegler \& Giambelluca (1997) simulated runoff and erosion on mountainous roads in northern Thailand using the KINEROS. The KINEROS was also applied for simulating badland erosion in a small Mediterranean mountain basin. Results demonstrated that the KINEROS was able to simulate badland erosion, although it showed limited robustness (Martínez-Carreras et al. 2007).

River systems in Malaysia consist of 1800 rivers with a total length of $38000 \mathrm{~km}$. Rapid development in Malaysia can change the natural hydrology and infiltration properties of the catchments because of the increase in the impermeable area. Urbanisation, deforestation and unmanaged agricultural activities are contributing to river pollution via the 


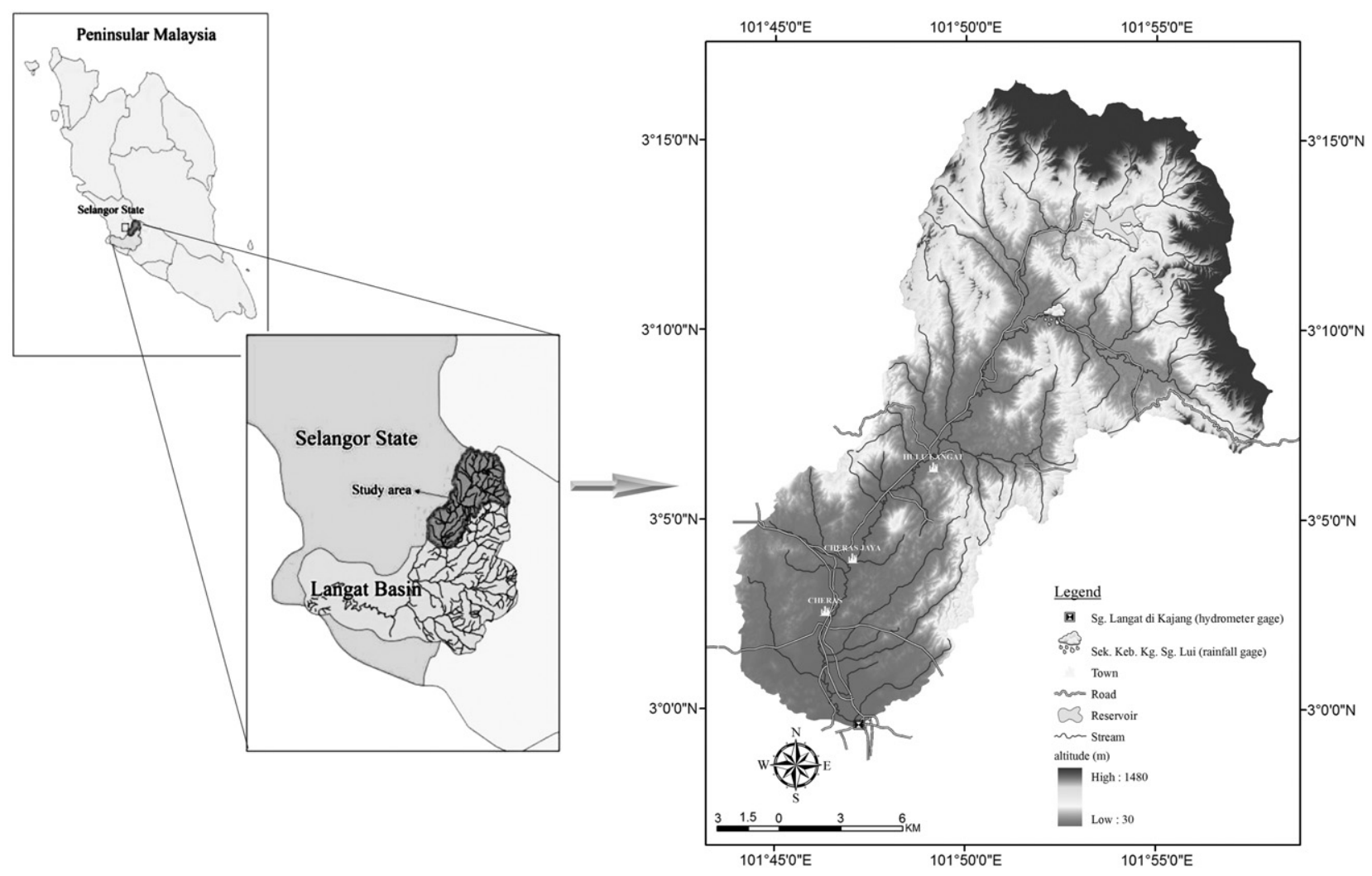

Fig. 1. Study area.

changes in soil physical properties and consequently erosion/ sediment processes. Surface runoff and sediments from these regions can lead to some on-site and off-site impacts (Ayub et al. 2009).

This work aimed at applying the K2 (an event-based model) for water/sediment yield prediction and land use/cover change (LUCC) impact investigation at the Hulu Langat basin.

\section{Materials and methods}

\section{Study area}

The Langat River Basin, located south of the Klang Valley, is the most urbanised river basin in Malaysia, and it is believed that the Langat Basin will compensate 'spillover' development from the Klang Valley. Hydrometeorologically, the basin is experiencing two types of the monsoons, that is, the Northeast (November to March) and the Southwest (May to September) (Noorazuan et al. 2003).

Based on available data about the Langat River Basin and the study objectives, the Hulu Langat sub-basin was selected for this study. The sub-basin is located between $3^{\circ} 00^{\prime}-3^{\circ} 17^{\prime}$ $\mathrm{N}$ and $101^{\circ} 44^{\prime}-101^{\circ} 58^{\prime} \mathrm{E}$ with an upstream area of 390.26 $\mathrm{km}^{2}$ and $34.5 \mathrm{~km}$ basin length on the upper part of the Langat
River Basin (Fig. 1). The average elevation is about $277.4 \mathrm{~m}$ above sea level. This sub-basin is steep with an average slope of $29.4 \%$. Average annual precipitation (based on 25 years of data) is $2453 \mathrm{~mm}$. According to the 2006 land use map, 54.6\% of the sub-basin area is occupied by forest and $15.6 \%$ by rubber while urbanised areas amount to $15 \%$. Orchards cover $2 \%$ of the sub-basin area, mixed horticulture covers $1.8 \%$ and the rest is mostly covered by oil palm, lake, marshland and mining activities. Dominant soil types in the sub-basin are steepland and Rengam-Jerangau soil series with sandy clay loam and clay textures, respectively.

\section{Data sets}

Hydrological data sets of the water discharge and sediment load for the Langat River were collected from the Department of Irrigation and Drainage, Malaysia. Precipitation data representing storm events were obtained from the rain gauge station number 3118102 , closest to the basin centroid. Land use maps dated 1984, 1990, 1997, 2002, 2006 and corresponding soil maps were obtained from the Department of Agriculture, Malaysia (Fig. 2). Digital topographic maps in the scale of 1-50 000 were utilised for digital elevation model extraction via linear interpolation. For extracting the Normal- 


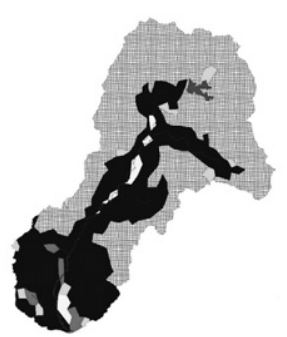

1984

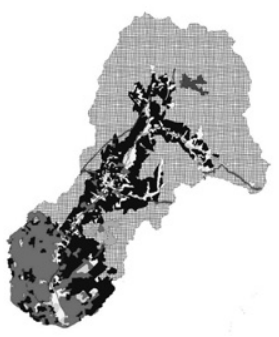

2002

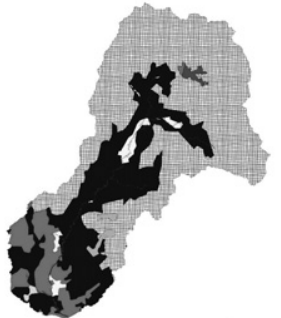

1990

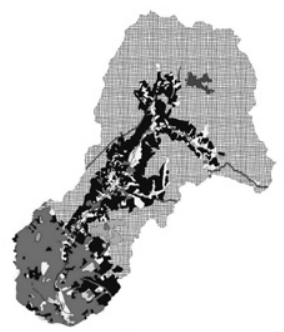

2006

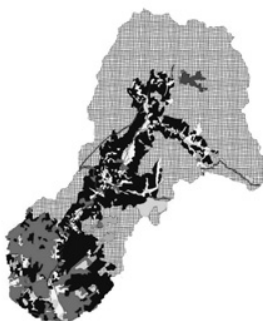

1997

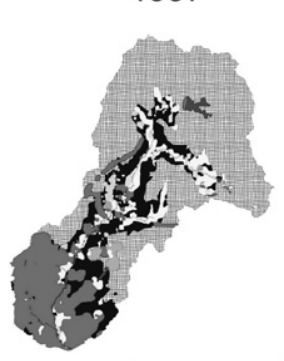

2020

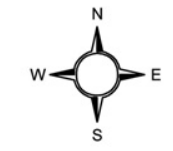

Land use

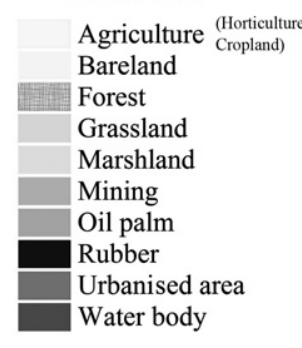
0 $10 \mathrm{~km}$
Fig. 2. Land use maps in different dates used in $\mathrm{K} 2$ simulation.

Table 1 Properties of selected storm events

\begin{tabular}{|c|c|c|c|c|c|c|}
\hline \multirow[b]{2}{*}{ Application } & \multirow[b]{2}{*}{ Date } & \multirow{2}{*}{$\begin{array}{l}\text { Duration } \\
\text { (h) }\end{array}$} & \multicolumn{2}{|l|}{ RF } & \multirow{2}{*}{$\begin{array}{l}I_{15 \_\max } \\
(\mathrm{mm} / \mathrm{h})\end{array}$} & \multirow{2}{*}{$\begin{array}{l}\text { I30_max } \\
(\mathrm{mm} / \mathrm{h})\end{array}$} \\
\hline & & & $\overline{\mathrm{mm}}$ & $\mathrm{m}^{3}$ & & \\
\hline \multirow[t]{2}{*}{ Calibration } & $10 / 09 / 97$ & 2.00 & 24.50 & 8415130.15 & 30.80 & 28.80 \\
\hline & $19 / 11 / 97$ & 3.25 & 40.10 & 13773335.47 & 47.20 & 41.80 \\
\hline \multirow[t]{2}{*}{ Validation } & $13 / 11 / 08$ & 4.00 & 41.10 & 14116810.17 & 52.40 & 36.20 \\
\hline & $03 / 11 / 84$ & 2.00 & 9.90 & 3400399.53 & 10.00 & 8.00 \\
\hline
\end{tabular}

I 15_max, maximum 15 min. intensity; I30_max, maximum 30 min. intensity; RF, rainfall.

ised Difference Vegetation Index (NDVI), satellite images dated 1990 and 2006 scanned by the thematic mapper sensors of Landsat were collected through the Global Land Cover Facility (http://glcf.umiacs.umd.edu/).

\section{Rainfall events}

In this study, three storm events with different intensities and durations at the northeast monsoon, southwest monsoon and inter-monsoon periods of the year 1997 were chosen for calibration and LUCC impact analysis (Table 1). Three other storms in the years 1984, 2008 (corresponding to the northeast monsoon) and 2006 (corresponding to the southwest monsoon) were selected to validate the model before and after the calibration year. There is only one recorder rain gauge with sufficient data for the period 1984-2008 inside the basin and outer stations suffer from lack of data. Therefore, with regard to this limitation and the need to evaluate LUCC impacts on the basin hydrology regime and comparing the response of different planes with land cover change, only one rain gauge station with isolated rainfall on the basin surface was utilised for simulation.

\section{K2}

The K2, an upgraded version of KINEROS (Woolhiser et al. 1990), is a physically event-based, distributed and dynamic model that predicts surface runoff, erosion losses, infiltration amount, and interception depth from the catchments, declared by predominantly overland flow (Smith et al. 1999; Semmens et al. 2008). In this model, the catchment is approximated by a cascade of overland flow planes, channels and impoundments. Overland flow planes can be split into multiple components with different slopes, roughness, soils, and so on. In this model, contiguous planes can have different width (Semmens et al. 2008). In overland flow conceptual model, small-scale spatial variability of infiltration can be represented in distribution sense and parameterised for 
Table 2 Average values of optimised sensitive parameters for different events applied in calibration and validation processes of K2

\begin{tabular}{|c|c|c|c|c|c|c|c|}
\hline Application & Storm event & KS_HS & $\mathrm{Ks} \_\mathrm{CH}$ & n_HS & n_CH & G_CH & $\mathrm{CV}_{-} \mathrm{Ks}$ \\
\hline \multicolumn{8}{|c|}{ Direct runoff simulation } \\
\hline \multirow[t]{2}{*}{ Calibration } & $10 / 09 / 97$ & 35.49 & 27.30 & 0.37 & 0.15 & 1.00 & 5.46 \\
\hline & $19 / 11 / 97$ & 28.39 & 42.00 & 0.64 & 0.25 & 2.00 & 2.34 \\
\hline \multirow[t]{2}{*}{ Validation } & $03 / 11 / 84$ & 10.14 & 46.20 & 0.11 & 0.09 & 4.00 & 1.56 \\
\hline & $13 / 11 / 08$ & 28.39 & 42.00 & 0.64 & 0.25 & 2.00 & 2.34 \\
\hline \multicolumn{8}{|c|}{ Sediment load simulation } \\
\hline \multirow[t]{3}{*}{ Calibration } & $10 / 09 / 97$ & 31.43 & 79.80 & 0.66 & 0.31 & 4.00 & 3.12 \\
\hline & $13 / 10 / 97$ & 18.25 & 63.00 & 0.25 & 0.31 & 10.00 & 2.34 \\
\hline & $19 / 11 / 97$ & 30.42 & 63.00 & 0.73 & 0.61 & 3.00 & 0.78 \\
\hline \multirow[t]{2}{*}{ Validation } & $03 / 11 / 84$ & 18.25 & 63.00 & 0.25 & 0.31 & 10.00 & 2.34 \\
\hline & $13 / 11 / 08$ & 30.42 & 63.00 & 0.73 & 0.61 & 3.00 & 0.78 \\
\hline
\end{tabular}

Ks_CH, saturated hydraulic conductivity for channels; Ks_HS, saturated hydraulic conductivity for hill slopes;

n_CH, Manning's roughness for channels; n_HS, Manning's roughness for hill slopes;

G_CH, mean capillary drive for channels; CV_Ks, coefficient of variations of Ks.

numerical efficiency. Furthermore, the K2 intercalates microtopography in simulation. Urban element models runoff based on pervious and impervious fractions (Semmens et al. 2008).

The model cannot simulate non-releasing ponds. Therefore, drainage area of the Langat reservoir was hydrologically eliminated from the simulation. Microtopographic properties on the planes and base flow rate at the catchments outlets were initialised, and for separating the base flow, local minimum method was applied on the data (Memarian et al. 2012a).

\section{Model calibration and validation}

Initial estimation of the sensitive parameters was performed using the KINEROS Manual (Woolhiser et al. 1990) and other literature sources (Arcement and Schneider, 1984; Abdul Ghaffar et al., 2004).

Both calibration and sensitivity analyses used a multiplier approach. In this approach, all initial estimates are increased or decreased by multiplying a factor. Table 2 shows the average values of optimised sensitive parameters during different simulations.

The statistical criteria used in this study were model bias $(\mathrm{MB})$, modified correlation coefficient $\left(r_{\text {mod }}\right)$ and NashSutcliffe efficiency (NS) (Nash \& Sutcliffe 1970; Safari et al. 2009; Memarian et al. 2012a). The perfect value for MB is 0 while that for the other evaluators is 1. For assessing the size, shape and volume of simulated hydrographs/sedigraphs, an aggregated measure (AM) was calculated as follows:

$$
A M=\frac{r_{\text {mod }}+N S+(1-|M B|)}{3}
$$

An AM value of 1 reflects a perfect fit. The AM is classified from very poor $(A M<0.4)$ to excellent $(A M>0.85)$ (Safari et al. 2009; Memarian et al. 2012a).

Model validation was performed based on the storm events before (1984) and after (2008 and 2006) the calibration year.

\section{Land use projection}

The cellular automata-Markov approach was used to model the 2020 land use map. The year 2020 is the target time so that by this year, Malaysia is targeted to be a fully developed country. CA-Markov modelling allows simulation of land changes among the multiple categories, and combines the $\mathrm{CA}$ and Markov chain procedure for land cover prediction (Eastman 2003). This procedure relaxes strict assumptions associated with the Markov approach and explicitly considers both spatial and temporal changes (Agarwal et al. 2002). Calibration of the CA-Markov was based on the changes in land cover during 1990-2002 (12 years). The 2006 land use map was used for validation using the Kappa measurement.

\section{Trend analysis}

Detection of significant gradual trends in the data, as a supporting analysis for the results of LUCC impact assessment, was performed using the Mann-Kendall (MK) and prewhitening Mann-Kendall (PWMK) tests (Memarian et al. 2012b). The non-parametric MK test was chosen because of its strength in dealing with missing data and non-normally distributed data (Zhang et al. 2008). 
Table 3 Fit metrics of calibration events for runoff and sediment modelling

\begin{tabular}{|c|c|c|c|c|c|c|}
\hline \multirow[b]{2}{*}{ Fitting metrics } & \multicolumn{3}{|c|}{ Direct runoff simulation } & \multicolumn{3}{|c|}{ Sediment load simulation } \\
\hline & 10/9/1997 & 13/10/1997 & 19/11/1997 & 10/9/1997 & 13/10/1997 & 19/11/1997 \\
\hline$\overline{M B}$ & -0.04 & -0.18 & -0.15 & -0.02 & 0.13 & 0.04 \\
\hline$r_{\text {mod }}$ & 0.84 & 0.77 & 0.93 & 0.84 & 0.85 & 0.81 \\
\hline NS & 0.81 & 0.78 & 0.84 & 0.69 & 0.80 & 0.77 \\
\hline AM & 0.87 & 0.79 & 0.87 & 0.84 & 0.84 & 0.85 \\
\hline Goodness of fit & Excellent & Very good & Excellent & Very good & Very good & Very good \\
\hline
\end{tabular}

Table 4 Fit metrics of validation events for runoff and sediment modelling

\begin{tabular}{|c|c|c|c|c|c|c|}
\hline \multirow[b]{2}{*}{ Fitting metrics } & \multicolumn{3}{|c|}{ Direct runoff simulation } & \multicolumn{3}{|c|}{ Sediment load simulation } \\
\hline & 03/11/1984 & $13 / 11 / 2008$ & 03/08/2006 & 03/11/1984 & $13 / 11 / 2008$ & 03/08/2006 \\
\hline $\mathrm{MB}$ & 0.28 & 0.10 & 0.30 & 0.11 & - & - \\
\hline$r_{\text {mod }}$ & 0.81 & 0.81 & 0.75 & 0.77 & 0.39 & 0.45 \\
\hline NS & 0.71 & 0.79 & 0.61 & 0.84 & -0.37 & -0.28 \\
\hline AM & 0.75 & 0.83 & 0.69 & 0.83 & - & - \\
\hline Goodness of fit & Very good & Very good & Good & Very good & Very poor & Very poor \\
\hline
\end{tabular}

Table 5 Variations of direct runoff and sediment load with land use change in different events

\begin{tabular}{|c|c|c|c|c|c|}
\hline \multirow[b]{2}{*}{ Year } & \multirow[b]{2}{*}{ Event } & \multirow{2}{*}{$\frac{\text { Volume of direct runoff }}{\mathrm{m}^{3}}$} & \multirow{2}{*}{$\frac{\text { Peak discharge }}{\mathrm{m}^{3 / s}}$} & \multicolumn{2}{|c|}{ Sediment load } \\
\hline & & & & $\mathrm{Kg} / \mathrm{ha}$ & tonnes \\
\hline \multirow[t]{4}{*}{1984} & $10 / 09 / 97$ & 128964.00 & 3.96 & 0.30 & 10.44 \\
\hline & $13 / 10 / 97$ & 166925.00 & 5.80 & 0.19 & 6.36 \\
\hline & $19 / 11 / 97$ & 198003.00 & 6.10 & 0.45 & 15.37 \\
\hline & Sum of events & 493892.00 & - & & 32.17 \\
\hline \multirow[t]{4}{*}{1990} & $10 / 09 / 97$ & 235323.00 & 7.99 & 0.48 & 16.50 \\
\hline & $13 / 10 / 97$ & 260276.00 & 10.05 & 0.41 & 14.21 \\
\hline & $19 / 11 / 97$ & 449577.00 & 12.90 & 0.97 & 33.48 \\
\hline & Sum of events & 945176.00 & - & & 64.19 \\
\hline \multirow[t]{4}{*}{1997} & 10/09/97 & 324266.00 & 11.29 & 1.00 & 34.25 \\
\hline & $13 / 10 / 97$ & 308410.00 & 13.35 & 1.11 & 38.24 \\
\hline & $19 / 11 / 97$ & 604549.00 & 20.10 & 3.41 & 117.21 \\
\hline & Sum of events & 1237225.00 & - & & 189.70 \\
\hline \multirow[t]{4}{*}{2002} & $10 / 09 / 97$ & 467420.00 & 18.18 & & \\
\hline & $13 / 10 / 97$ & 369012.00 & 17.74 & & \\
\hline & $19 / 11 / 97$ & 834647.00 & 29.69 & & \\
\hline & Sum of events & 1671079.00 & - & & \\
\hline \multirow[t]{4}{*}{2006} & 10/09/97 & 563047.00 & 22.18 & & \\
\hline & $13 / 10 / 97$ & 419006.00 & 20.40 & & \\
\hline & $19 / 11 / 97$ & 985406.00 & 33.81 & & \\
\hline & Sum of events & 1967459.00 & - & & \\
\hline \multirow[t]{4}{*}{2020} & 10/09/97 & 712880.00 & 31.92 & & \\
\hline & $13 / 10 / 97$ & 493332.00 & 26.16 & & \\
\hline & $19 / 11 / 97$ & 1205839.00 & 43.50 & & \\
\hline & Sum of events & 2412051.00 & - & & \\
\hline
\end{tabular}

\section{Landscape analysis}

Changes in land use patterns over the period 1984-2020 in various land use maps were assessed using the Patch Analyst 3.0 (Grid) extension in ArcView, a GIS program developed and produced by Northwest Science and Technology, Ontario, Canada. The four main landscape metrics (Elkie et al. 1999):
(1) patch size coefficient of variation (PSCOV), (2) edge density (ED), (3) Shannon's diversity index (SDI), and (4) number of patches (NUMP) were utilised as fundamental indices to detect the trends in land use change and to support the results of LUCC impact investigations (Ouyang et al. 2010b; Memarian et al. 2012b). 

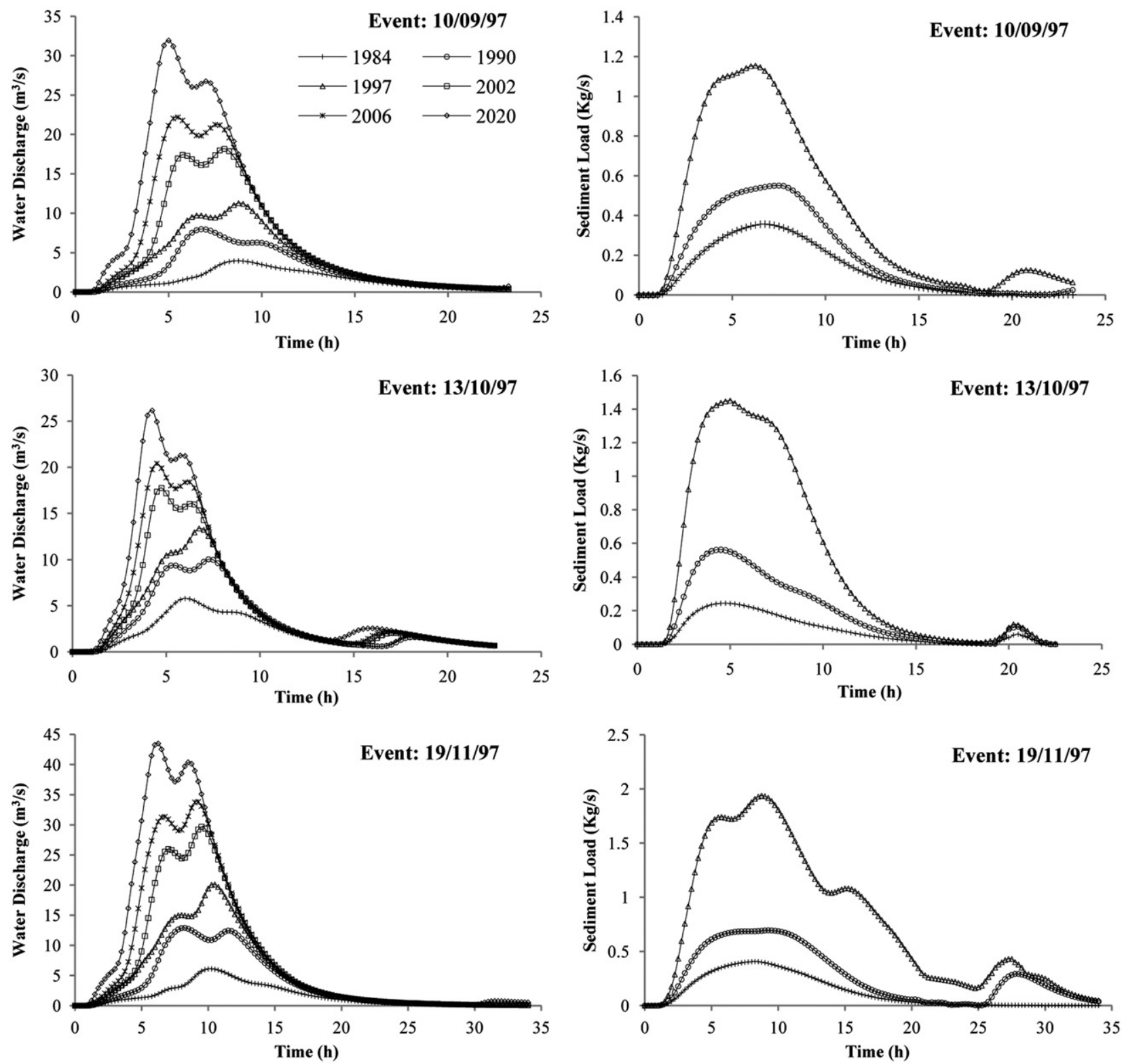

Fig. 3. Simulated hydrographs and sedigraphs for three selected events.

\section{Vegetation Analysis}

Relationship between land degradation and cover change was established based on the NDVI (Wessels et al. 2004; Zhou et al. 2008; Ouyang et al. 2010a). In this work, results of NDVI analysis were compared with results of LUCC impact analysis, simulated by the $\mathrm{K} 2$.

Analysis of LUCC impacts on the hydrological conditions of the basin was performed using an optimised K2 under Automated Geospatial Watershed Assessment tool interface. Various land use maps (1984-2020) of the Hulu Langat basin

were fed into the model, and simulation was performed using the storm events used in the calibration process.

\section{Results}

\section{Calibration and validation}

Calibration results of runoff simulation (Table 3 ) indicated that the MB was highest for the event dated 13 October 1997 (MB $=-0.18)$ while the storm on 19 November 1997 presented the highest $r_{\text {mod, }}$ NS and AM. Categorically, the events 

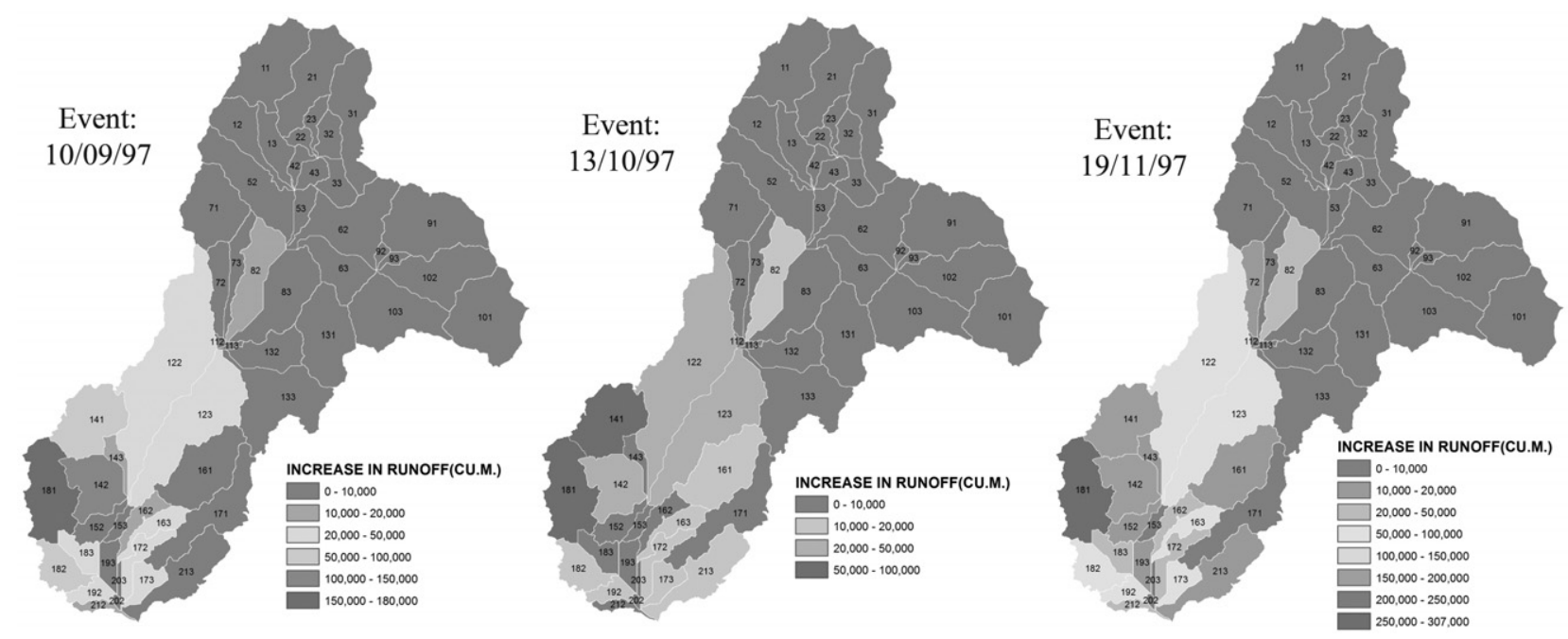

Fig. 4. Increased runoff volume $\left(\mathrm{m}^{3}\right)$ in 2020 compared with 1984 for different events.
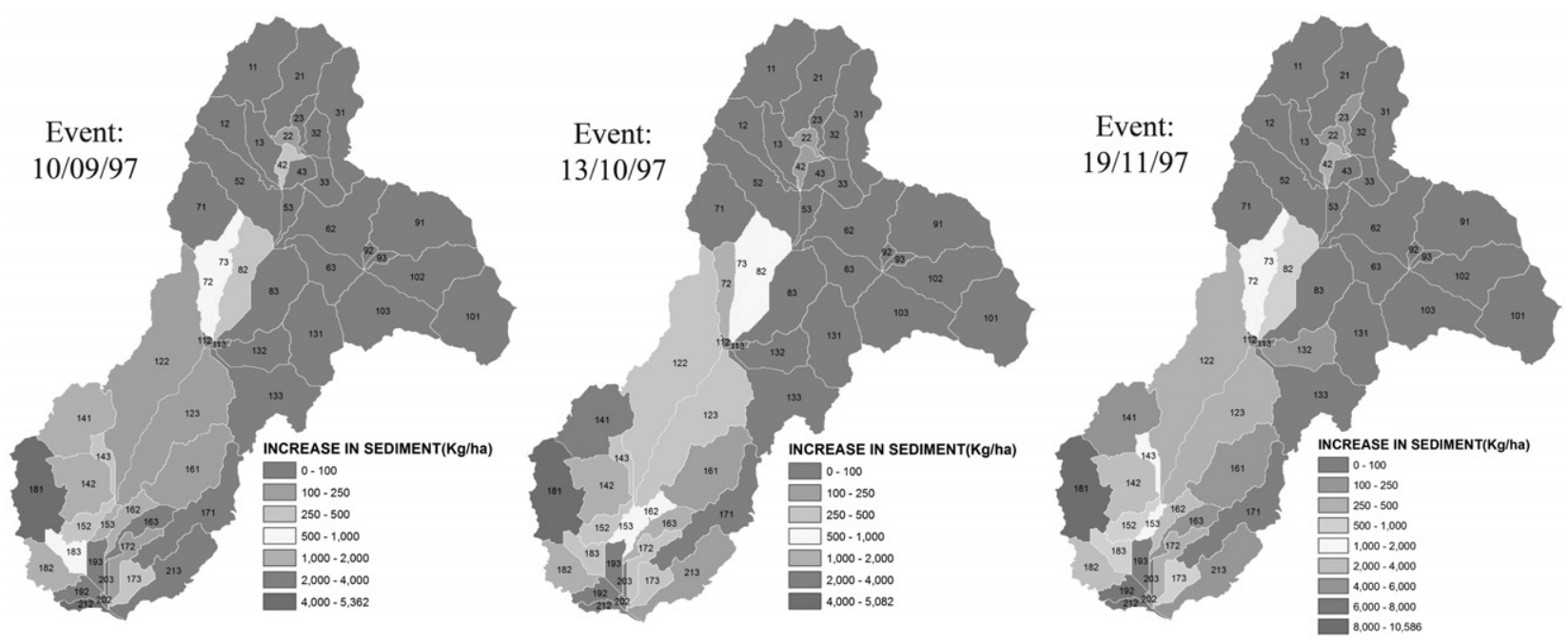

Fig. 5. Increased sediment load (kg/ha) in 1997 compared with 1984 for different events.

dated 09 October 1997 and 19 November 1997 were classed as excellent while the event dated 13 October 1997 was classed as very good, in terms of fit goodness. AMs in sediment simulation were almost the same for all events except for 19 November 1997. But this storm indicates more simulation accuracy $(\mathrm{AM}=0.85)$ due to lower bias $(\mathrm{MB}=0.04)$ and higher NS (0.77) than the other events (Memarian et al. 2012a).

Validation results showed that the $\mathrm{K} 2$ was able to simulate runoff with high accuracy (both before and after the calibration year) (Table 4). However, sediment yield simulation showed only high accuracy for the 1984 event. The K2 overestimated sediment load for the events after 1997, especially in developed parts of the basin. The simulated sediment load for 2008 and 2006 (based on the 2006 land use map) was around five times the actual amount (Memarian et al. 2012a).

\section{LUCC impact assessment}

The CA-Markov approach for future land use projection (year 2020) presented $88 \%$ overall accuracy in validation process. Due to lack of reliability for sediment simulation after 1997, the K2 was only run for sediment load estimation in the period 1984-1997.

The results showed that peak discharge for the event dated 10 September 1997 will increase almost sevenfold, that is, from $3.96 \mathrm{~m}^{3} / \mathrm{s}$ in 1984 to $31.92 \mathrm{~m}^{3} / \mathrm{s}$ in 2020 . This pattern was similar for the other storm events (Table 5 and 
Table 6 Dominant land uses in 1984 and 2020 for planes with a runoff increase higher than $10000 \mathrm{~m}^{3}$, as a result of the event dated $13 / 10 / 97$

\begin{tabular}{lll}
\hline & & \\
Plane & Dominant uses_1984 & Dominant uses_2020 \\
\hline 181 & Rubber & Urban \\
141 & Forest, Rubber & Urban, Forest \\
122 & Forest, Rubber & increase $\left(\mathrm{m}^{3}\right)$ \\
142 & Rubber, Urban & Forest, Urban, Rubber \\
123 & Rubber, Forest & Urban \\
182 & Rubber, Urban, Grassland & Rubber, Urban, Forest, Mining, Agriculture \\
192 & Rubber & Urban \\
213 & Rubber & Urban \\
163 & Rubber & Urban, Rubber \\
173 & Rubber, Urban, Agriculture & Urban \\
82 & Rubber, Forest, Agriculture & Urban \\
161 & Rubber, Forest & Rubber, Urban, Agriculture \\
172 & Rubber, Agriculture & Rubber, Urban, Mining, Bareland \\
\hline
\end{tabular}

Fig. 3). The results also showed that direct runoff volume will increase almost fourfold in 2020, as compared with that in 1984 (Table 5). The increasing trend of sediment load was evident between 1984 and 1997, where sediment yields in 1984 at $10.44,6.36$ and 15.37 (tons) increased by 34.25 , 38.24 and 117.21 (tons) in 1997 for the events on September, October and November, respectively (Table 5). As illustrated in Fig. 3, with urban development within the basin, hydrographs and sedigraphs that were unimodal in shape transformed into bimodal shape. This is probably due to faster evacuation of the flood from the developed planes than that from the non-developed planes.

The volume of runoff from the overland flow planes 82, 122, $123,141,142,161,162,163,172,173,181,182$ and 192 in 2020 is predicted to increase up to $180000 \mathrm{~m}^{3}, 100000 \mathrm{~m}^{3}$, and $307000 \mathrm{~m}^{3}$ for the events dated 10 September 1997, 13 October 1997, and 19 November 1997, respectively, as compared with the year 1984 (Fig. 4). Sediment load from the planes 42, 72, 82, 141, 142, 143, 153, 162, 163, 173, 181, 183 and 212 in 1997 is predicted to increase up to 1290,736 and $1805 \mathrm{~kg} / \mathrm{ha}$ for the events dated 10 September 1997, 13 October 1997, and 19 November 1997, respectively, as compared with the year 1984 (Fig. 5). These planes are subjected to the most intense urban and agricultural development.

\section{Discussion}

\section{Model calibration and validation}

Calibration results confirmed that the $\mathrm{K} 2$ overpredicts peak water discharge for the events with high intensities and durations (10 September 1997 and 19 November 1997), also overpredicts peak sediment discharge for the event with low intensity (13 October 1997). This could be caused by the fact that only one rain gauge station was used, and only one isolated storm event on the watershed surface was considered (Hernandez et al. 2000; Memarian et al. 2012a).

The K2 was not valid for sediment simulation of the events after 1997. With increasing urbanisation in the southern planes of the basin, surface runoff (simulated by the K2) increased substantially. Increased surface runoff accelerated the stream transport capacity, thus reducing the deposition amount. Water and sediment from the upstream planes flowed toward the outlet, and because of high transport capacity in the stream, a second peak was created in the sedigraph. This led to the overprediction of sediment discharge. The results also showed that simulated direct runoff follows a linear trend while simulated sediment load trend is non-linear during the period 1984-2008. Meanwhile, the actual sediment load follows a linear trend over the period 1984-2008 (Memarian et al. 2012a). This demonstrates that K2 overpredicts sediment load after the year 1997. Furthermore, the Hulu Langat basin has been subjected to extensive anthropogenic manipulations in hydrological status. Some landforms resulting from urban development and agricultural activities were not captured in land use and topography maps. This omission included most of the ponds at the Hulu Langat basin, which can affect sedimentation process through increased deposition rate (Memarian et al. 2012a, 2012b).

\section{LUCC impact assessment}

To demonstrate the impact of land use change on the basin hydrological status, the overland flow planes with the most intense hydrological change were examined in terms of LUCC. For example, because of land use shift from rubber (in 1984) to urbanised area (in 2020), direct runoff from the plane 181 will change up to $99290.1 \mathrm{~m}^{3}$, and sediment load from the plane 142 will change up to $735.3 \mathrm{~kg} / \mathrm{ha}$ (in 1997). As 
Table 7 Dominant land uses in 1984 and 1997 for planes with a sediment load increase higher than 100 kg/ha, as a result of the event dated 13/10/97

\begin{tabular}{|c|c|c|c|}
\hline Plane & Dominant uses_1984 & Dominant uses_1997 & $\begin{array}{l}\text { Sediment load } \\
\text { increase (kg/ha) }\end{array}$ \\
\hline 142 & Rubber, Urban & Urban, Agriculture & 735.28 \\
\hline 141 & Forest, Rubber & Forest, Urban & 561.41 \\
\hline 153 & Rubber, Urban, Grassland & Urban, Agriculture, Rubber & 555.54 \\
\hline 163 & Rubber & Urban, Grassland, Rubber & 551.18 \\
\hline 183 & Rubber & Urban & 312.59 \\
\hline 42 & Rubber & Rubber, Forest, Agriculture, Urban & 282.62 \\
\hline 143 & Rubber & Urban, Rubber, Agriculture & 243.92 \\
\hline 162 & Rubber, Grassland & Rubber, Urban, Agriculture, Oil palm & 215.07 \\
\hline 72 & Forest, Rubber & Rubber, Forest, Grassland & 189.60 \\
\hline 82 & Rubber, Forest, Agriculture & Rubber, Agriculture, Forest, Urban & 185.07 \\
\hline 152 & Rubber & Urban, Rubber, Oil palm & 133.012 \\
\hline
\end{tabular}

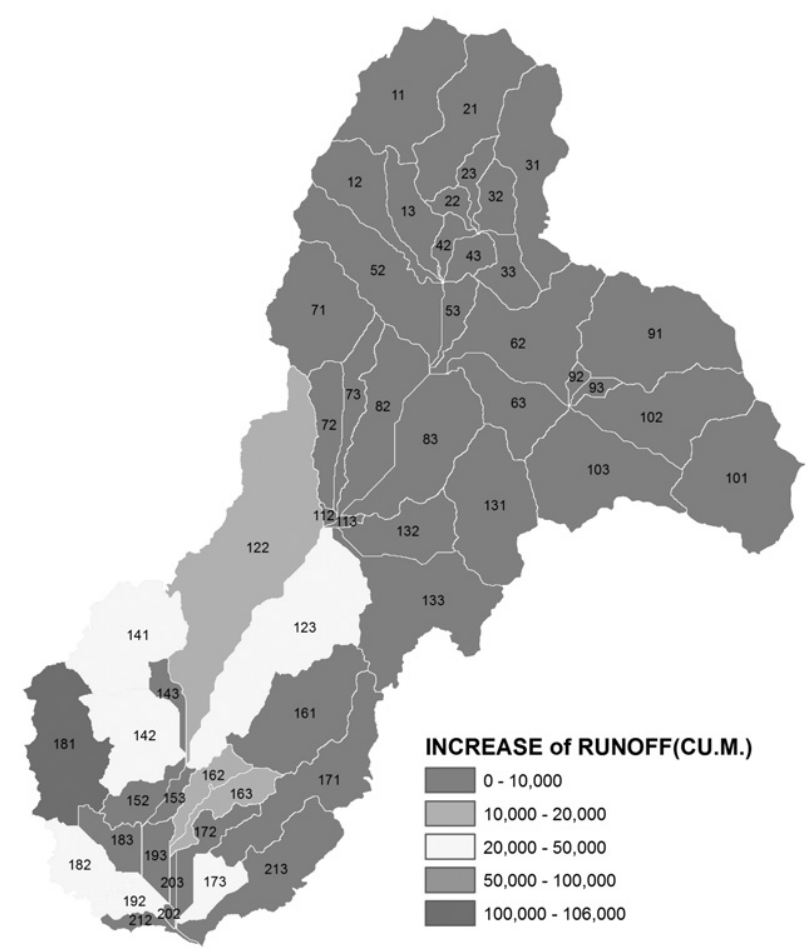

Fig. 6. Mean of increase in runoff volume in 2006 compared with 1990.

given in Tables 6 and 7, increase in land use change intensity will cause large changes in direct runoff and sediment load.

NDVI comparisons demonstrated a negative effect of land cover change on the basin status. Figure 6 illustrates an increase in runoff volume in 2006 , as compared with that in 1990. The planes with the highest increase in runoff volume, that is, 123, 141, 142, 181, 182, 192 and 173, are well matched with the planes that show a high amount of NDVI reduction (Figs 7 and 8 ).
The MK and PWMK tests with the Sen's slope estimator (at $\alpha=0.05)$, applied on the annual water discharge and sediment load time series, also affirmed increasing trends of the water discharge and sediment load during the 1984-2008 period. Water discharge in the Hulu Langat basin increased significantly at a rate of $9.899 \times 10^{6} \mathrm{~m}^{3} / \mathrm{year}$. Further investigations showed that increasing trend in water discharge at the Hulu Langat basin was originally controlled by significant variations in land use and rainfall. However, the increasing rate of sediment load $\left(1.415 \times 10^{3}\right.$ tons/yr) at the corresponding recording station was not significant, mainly due to dam construction and increase in number and size of sediment trapping features, which is due to urbanisation and agricultural activities (Memarian et al. 2012b).

Because of increase in number of patches and landscape diversity from 1984 to 2020, all landscape metrics showed significant increasing trends, analysed by the MK test (Fig. 9) (Memarian et al. 2012b). The relationships between landscape metrics and hydrological time series at the Hulu Langat basin have been reported by Memarian et al. (2012b). These observations are in conformity to Weng (2007).

Taken together, these findings with the work of Noorazuan et al. (2003), Juahir (2009), Juahir et al. (2010) and Memarian et al. (2012b) demonstrate the impact of LUCC on the hydrological response of the basin under study. Similar findings were reported in other studies (Hernandez et al. 2000; Nearing et al. 2005; Kepner et al. 2008).

\section{Conclusion}

(1) Based on K2 calibration, it was clear that in spite of close fits between observed and predicted values for runoff and sediment load, overprediction occurred with the peak discharge for the events with high intensities and durations, and with the peak sediment discharge for the events with low intensity. 


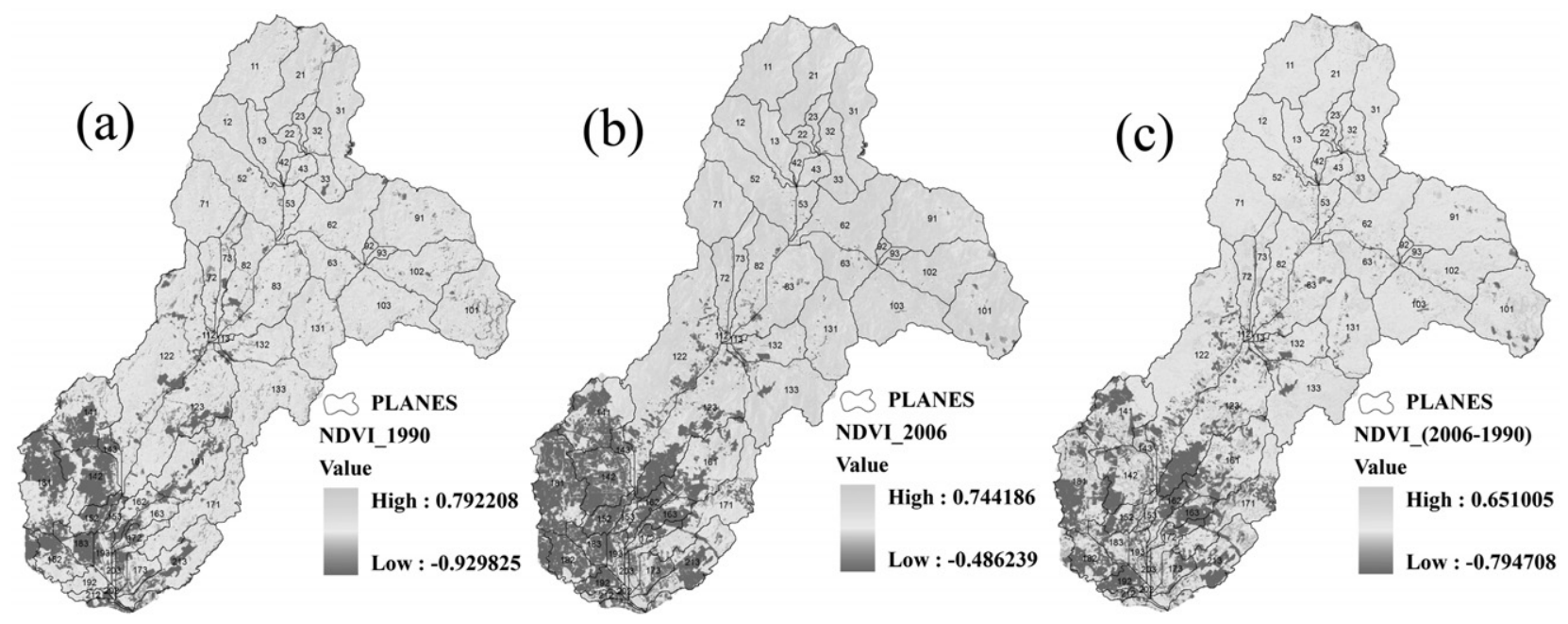

Fig. 7. (a) NDVI map dated 1990, (b) NDVI map dated 2006, (c) NDVI difference between 2006 and 1990 based on standardised values.

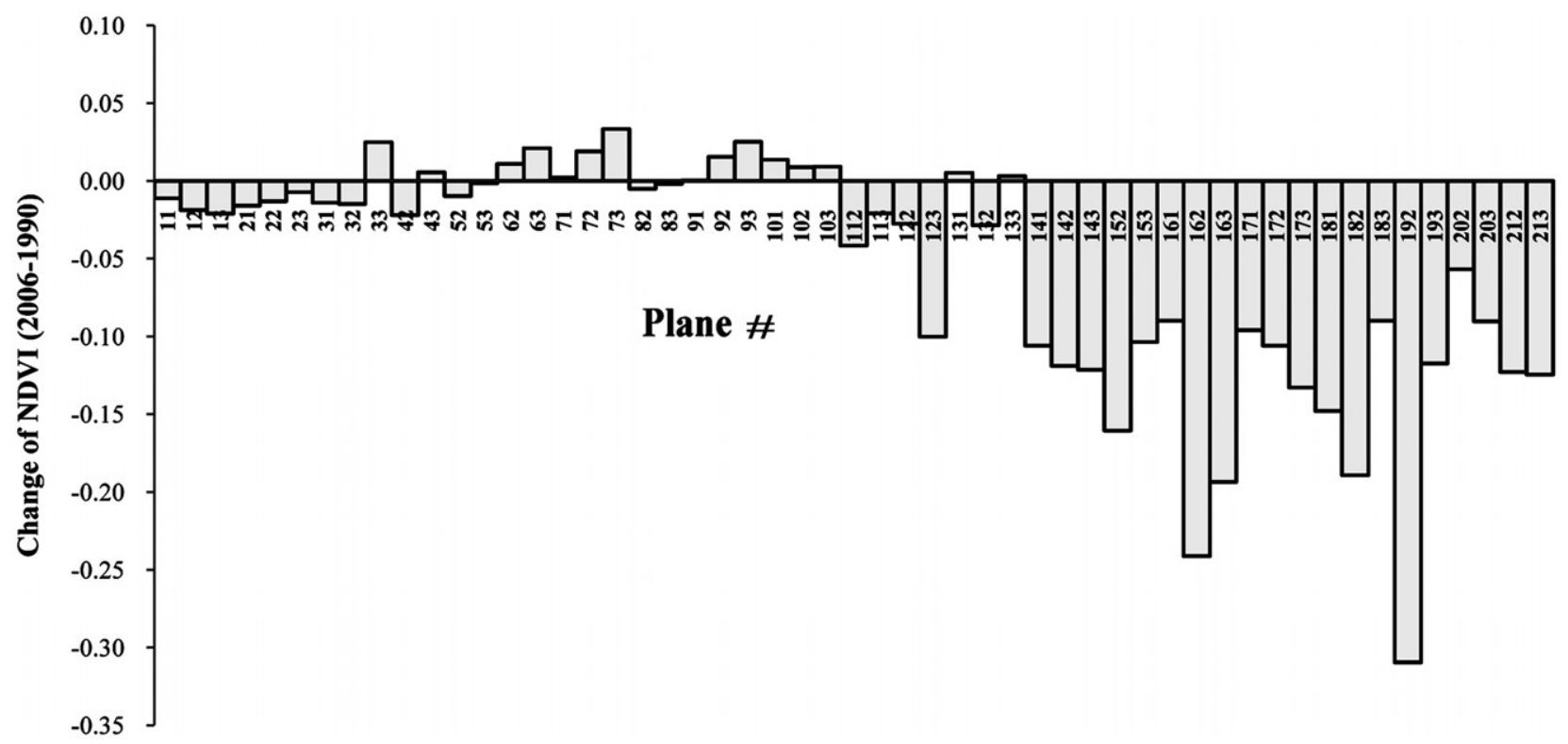

Fig. 8. Change of NDVI in 2006 as compared with 1990 for different planes based on standardised values.

(2) Based on the validation analysis, sediment load simulation using the K2 was not valid for the events after 1997, mostly attributable to missing features in land use maps, such as ponds, which trap sediments.

(3) Running the $\mathrm{K} 2$ with different land use information between 1984 and 2020 showed that sediment load, peak discharge and runoff volume from the most developed planes increased in tandem with increased urbanisation, industrialisation, and unmanaged agricultural activities. LUCC impact analysis revealed that runoff volume from the developed regions will change up to $180000 \mathrm{~m}^{3}, 100000 \mathrm{~m}^{3}$, and
$307000 \mathrm{~m}^{3}$ for the events dated 10 September 1997, 13 October 1997 and 19 November 1997, respectively, over the period 1984-2020. Meanwhile, sediment load differences from the developed planes in the southern part of the basin were $1290 \mathrm{~kg} / \mathrm{ha}, 736 \mathrm{~kg} / \mathrm{ha}$, and $1805 \mathrm{~kg} / \mathrm{ha}$ for the events dated 10 September 1997, 13 October 1997 and 19 November 1997, respectively, over the period 1984-1997. These findings were supported by NDVI analysis, hydrological trend analysis and landscape investigation, also representing significant alterations in the basin hydrological process and consequently entire ecosystem. 

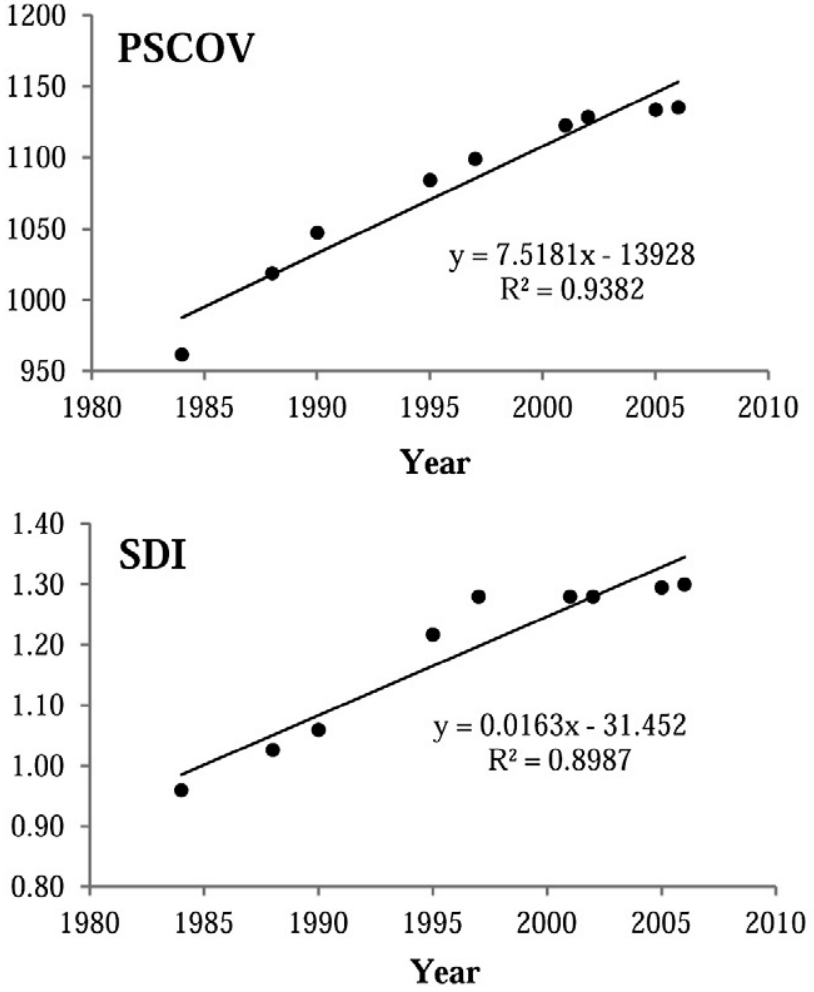

Fig. 9. Trends of selected landscape metrics during 1984-2006.

\section{Acknowledgements}

The authors acknowledge Universiti Putra Malaysia for procuring land use, soil and satellite data, and the Department of Irrigation and Drainage, Malaysia for supplying necessary hydrological data.

To submit a comment on this article please go to http://mc.manuscriptcentral.com/wej. For further information please see the Author Guidelines at wileyonlinelibrary.com

\section{References}

Abdul Ghaffar, A.B., Ghani, A.A., Zakaria, N.A., Abu Hasan, Z. and Kiat, C.C. (2004) Determining Manning's flow resistance coefficient for rivers in Malaysia. 1st International Conference on Managing Rivers in the 21st Century: Issues and Challenges, Penang, Malaysia, pp. 104-110.

Agarwal, C., Green, G.M., Grove, J.M., Evans, T.P. and Schweik, C.M. (2002) A Review and Assessment of Land-Use Change Models: Dynamics of Space, Time, and Human Choice. General Technical Report NE-297. U.S. Department of Agriculture, Forest Service, Northeastern Research Station, Newtown Square, Pennsylvania. $61 \mathrm{pp}$.

Arcement Jr, G.J. and Schneider, V.R. (1984) Guide for Selecting Manning's roughness coefficients for natural channels and flood plains. Water Supply Paper \#2339, Metric Version. United States Geological Survey, 67 pp. Available at http:// www.fhwa.dot.gov/bridge/wsp2339.pdf [accessed 20 March 2011].
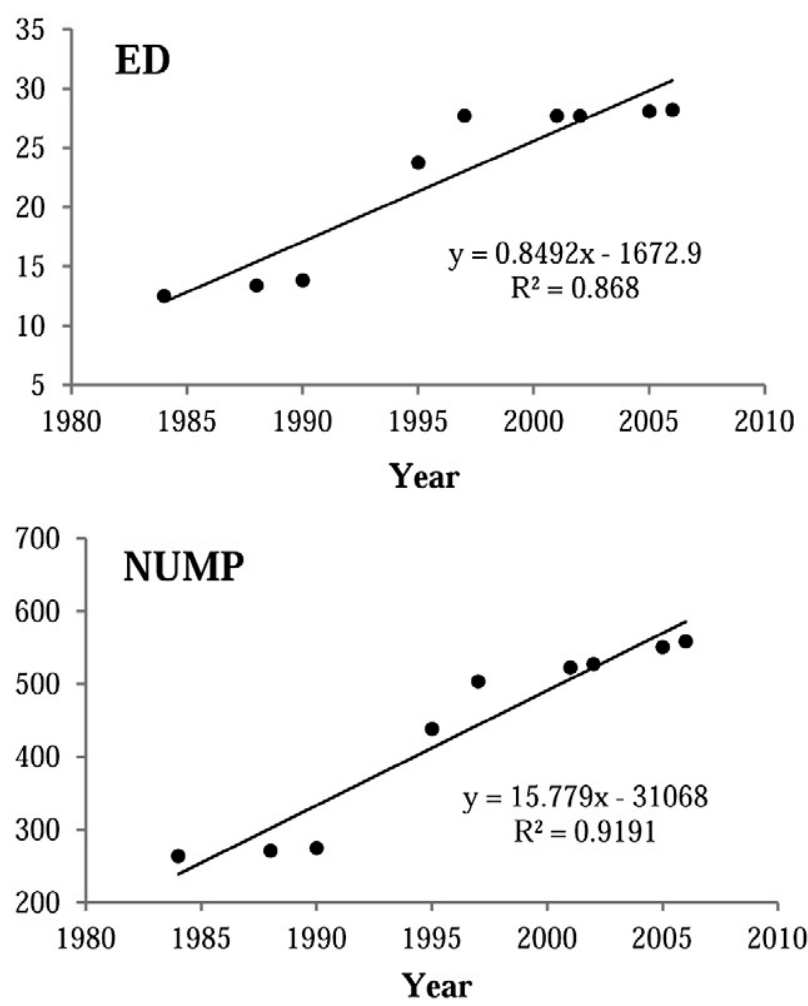

Ayub, K.R., Hin, L.S. and Aziz, H.A. (2009) SWAT Application for Hydrologic and Water Quality Modelling for Suspended Sediments: A Case Study of Sungai Langat's Catchment in Selangor. International Conference on Water Resources (ICWR), Langkawi, Kedah, Malaysia.

Eastman, J.R. (2003) IDRISI Kilimanjaro, Guide to GIS and Image Processing. Worcester, Clark Labs.

Elkie, P., Rempel, R. and Carr, A. (1999) Patch Analyst User's Manual. Ontario Ministry of Natural Resources, Northwest Science and Technology. Thunder Bay, Ont. TM-002. 16 pp + Appendix.

García-Ruiz, J.M., Regüés, D., Alvera, B., Lana-Renault, N., Serrano-Muela, P., Nadal-Romero, E. et al. (2008) Flood Generation and Sediment Transport in Experimental Catchments Affected by Land Use Changes in the Central Pyrenees. Journal of Hydrology, 356 (1-2), 245-260.

Ghaffari, G., Keesstra, S., Ghodousi, J. and Ahmadi, H. (2009) SWAT-Simulated Hydrological Impact of Land-Use Change in the Zanjanrood Basin, Northwest Iran. Hydrological Processes.

He, H., Zhou, J. and Zhang, W. (2008) Modelling the Impacts of Environmental Changes on Hydrological Regimes in the Hei River Watershed, China. Glob. Planet. Change, 61 (3-4), 175-193.

Hernandez, M., Miller, N.S., Goodrich, D.C., Goff, B.F., Kepner, W.G., Edmonds, C.M. and Jones, K.B. (2000) Modelling Runoff Response to Land Cover and Rainfall Spatial Variability in Semi-Arid Watersheds. Environ. Monit. Assess., 64, 285-298. 
Juahir, H. (2009) Water quality data analysis and modelling of the Langat River basin. PhD Thesis, Faculty of Science, University of Malaya, Kuala Lumpur, pp. 68-138.

Juahir, H., Zain, S.M., Yusoff, M.K., Hanidza, T.I.T., Armi, A.S.M., Toriman, M.E. and Mokhtar, M. (2010) Spatial Water Quality Assessment of Langat River Basin (Malaysia) Using Environmetric Techniques. Environmental Monitoring and Assessment. Published online at http://www.Springerlink.com.

Kepner, W.G., Hernandez, M., Semmens, D.J. and Goodrich, D.C. (2008) The Use of Scenario Analysis to Assess Future Landscape Change on Watershed Condition in the Pacific Northwest (USA). In Petrosillo, I. et al. (ed) Use of Landscape Sciences for the Assessment of Environmental Security, pp. 237-261. Springer, Dordrecht, The Netherlands.

Li, Z., Liu, W.Z., Zhang, X.C. and Zheng, F.L. (2009) Impacts of Land Use Change and Climate Variability on Hydrology in an Agricultural Catchment on the Loess Plateau of China. Journal of Hydrology, 377 (1-2), 35-42.

Martínez-Carreras, N., Soler, M., Hernández, E. and Gallart, F. (2007) Simulating Badland Erosion with KINEROS2 in a Small Mediterranean Mountain Basin (Vallcebre, Eastern Pyrenees). Catena, 71, 145-154.

Memarian, H., Balasundram, S.K., Talib, J., Teh, C.B.S., Alias, M.S., Abbaspour, K.C. and Haghizadeh, A. (2012a) Hydrologic Analysis of a Tropical Watershed Using KINEROS2. EnvironmentAsia, 5 (1), 84-93.

Memarian, H., Balasundram, S.K., Talib, J., Alias, M.S. and Abbaspour, K.C. (2012b) Trend Analysis of Water Discharge and Sediment Load during the past Three Decades of Development in the Langat Basin, Malaysia. Hydrological Sciences Journal, 57 (6), 1207-1222.

Miller, S.N., Semmens, D.J., Goodrich, D.C., Hernandez, M., Miller, R.C., Kepner, W.G. and Guertin, D.P. (2007) The Automated Geospatial Watershed Assessment Tool. Environmental Modelling and Software, 22, 365-377.

Nash, J.E. and Sutcliffe, J.V. (1970) River Flow Forecasting through Conceptual Models. Part I. A Discussion of Principles. Journal of Hydrology, 10 (3), 282-290.

Nearing, M.A., Jetten, V., Baffaut, C., Cerdan, O., Couturier, A., Hernandez, M. et al. (2005) Modelling Response of Soil Erosion and Runoff to Changes in Precipitation and Cover. Catena, 61 (2-3), 131-154.

Noorazuan, M.H., Rainis, R., Juahir, H., Zain, S.M. and Jaafar, N. (2003) GIS Application in Evaluating Land Use-Land Cover Change and Its Impact on Hydrological Regime in Langat River Basin, Malaysia. Conference of Map Asia, Malaysia, Kuala Lumpur. http://www.geospatialworld.net/ index.php?option=com_content\&view=article\&id=15467 [accessed 10 September 2010].
Ouyang, W., Hao, F., Skidmore, A.K. and Toxopeus, A.G. (2010a) Soil Erosion and Sediment Yield and Their Relationships with Vegetation Cover in Upper Stream of the Yellow River. Sci. Total Environ., 409, 396-403.

Ouyang, W., Skidmore, A.K., Hao, F. and Wang, T. (2010b) Soil Erosion Dynamics Response to Landscape Pattern. Sci. Total Environ., 408 (6), 1358-1366.

Safari, A., De Smedt, F. and Moreda, F. (2009) WetSpa Model Application in the Distributed Model Intercomparison Project (DMIP2). J. Hydrol., 418-419, 78-89.

Semmens, D.J., Goodrich, D.C., Unkrich, C.L., Smith, R.E., Woolhiser, D.A. and Miller, S.N. (2008) KINEROS2 and the AGWA Modeling Framework. In Wheater, H., Sorooshian, S. and Sharma, K.D. (eds). Hydrological Modelling in Arid and SemiArid Areas, p. 206. Cambridge University Press, New York.

Smith, R.E., Goodrich, D.C. and Unkrich, C.L. (1999) Simulation of Selected Events on the Catsop Catchment by KINEROS2, a Report for the GCTE Conference on Catchment Scale Erosion Models. Catena, 37, 457-475.

Sorooshian, S. and Gupta, V.K. (1995) Model Calibration. In Singh, V.P. (ed). Computer Models of Watershed Hydrology, pp. 23-68. Water Resources Publications, Colorado.

Weng, Y.C. (2007) Spatiotemporal Changes of Landscape Pattern in Response to Urbanisation. Landsc. Urban Plan., 81 (4), 341-353.

Wessels, K.J., Prince, S.D., Frost, P.E. and van Zyl, D. (2004) Assessing the Effects of Human-Induced Land Degradation in the Former Homelands of Northern South Africa with a $1 \mathrm{Km}$ AVHRR NDVI Time-Series. Remote Sens. Environ., 91, 47-67.

Woolhiser, D.A., Smith, R.E. and Goodrich, E.C. (1990) A Kinematic Runoff and Erosion Model: Documentation and User Manual, U.S. Department of Agriculture. Agricultural Research Service, ARS-77. $130 \mathrm{pp}$.

Zhang, S., Lu, X.X., Higgitt, D.L., Chen, C.T.A., Han, J. and Sun, H. (2008) Recent Changes of Water Discharge and Sediment Load in the Zhujiang (Pearl River) Basin, China. Glob. Planet. Change, 60 (3-4), 365-380.

Zhang, X., Cao, W., Guo, Q. and Wu, S. (2010) Effects of Landuse Change on Surface Runoff and Sediment Yield at Different Watershed Scales on the Loess Plateau. Int. J. Sediment. Res., 25 (3), 283-293.

Zhou, P., Luukkanen, O., Tokola, T. and Nieminen, J. (2008) Effect of Vegetation Cover on Soil Erosion in a Mountainous Watershed. Catena, 75, 319-325.

Ziegler, A.D. and Giambelluca, T.W. (1997) Simulation of Runoff and Erosion on Mountainous Roads in Northern Thailand: A First Look. Human Impact on Erosion and Sedimentation. Proceedings of Rabat Symposium S6, IAHS. Publication no. 245. 